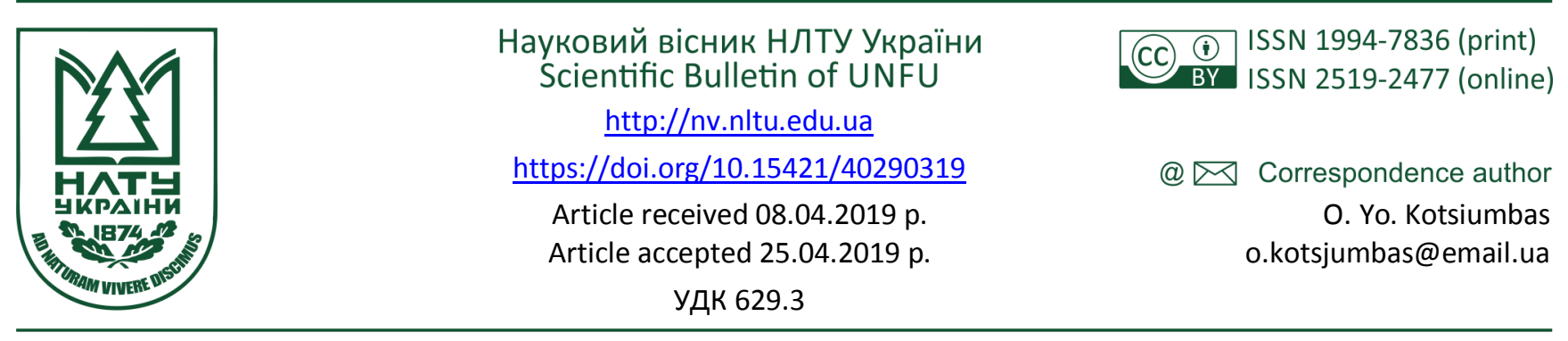

V. M. Korendiy, O. Yo. Kotsiumbas, O. V. Lanets

Lviv Polytechnic National University, Lviv, Ukraine

\title{
ANALYSIS OF TECHNICAL AND OPERATIONAL CHARACTERISTICS OF TURNING-AND- SHUNTING DOOR OPENING MECHANISM OF ELECTRIC PUBLIC TRANSPORT
}

One of the most important problems occurring while designing public transport vehicles consists in providing an effective control of the door opening systems. The methods of carrying out the investigations presented in the paper include structural and kinematic analysis of the door opening mechanisms and simulation of their operation in applied software. The paper analyses the design and operational peculiarities of the turning-and-shunting mechanism of door opening of electric public transport. The corresponding design of the mechanism is proposed. It is suggested to be driven by pneumatic drive. The simplified diagram of the mechanism is constructed. Structural and kinematic analysis of the mechanism is performed, and the analytical dependencies for describing the motion of its links during the door opening/closing are derived. The main kinematic parameters of the studied mechanism are investigated on the basis of the derived analytical dependencies in MathCAD software, as well as by means of simulating the motion of the solid-state model of the mechanism designed in SolidWorks software. The conclusions about the agreement of the results of theoretical investigations performed on the basis of numerical solving the obtained motion equations and of the virtual experiment (motion simulation in SolidWorks software) are drawn. The analysis of energy efficiency of the investigated turning-and-shunting door opening mechanism of electric public transport is carried out. Prescribing the resistance force acting on the door leaf and calculating the corresponding door motion speed during its closing, the dependency of the nominal power supply of the mechanism drive as a function of corresponding generalized coordinates was deduced. Analyzing the obtained results, the authors have established that the necessary nominal power of the turning-and-shunting mechanism drive is almost twice larger than the necessary nominal power of the widely used leaning-and-shunting mechanism. Further investigations on the subject of the paper can be performed in the direction of developing different control systems providing safe and reliable operation of the considered door opening mechanism driven be electric and pneumatic actuators.

Keywords: turning-and-shunting mechanism; electric public transport; structural analysis; kinematic analysis; energy efficiency.

Introduction. Modern living standards cause the growth of the citizens' needs in a faster, convenient and safe transportation. One of the most important problems occurring while designing electric public vehicles is the problem of controlling the mechanisms for opening/closing doors. At the present time, there are dozens of designs of these mechanisms, which differ from each other by the following features: the direction of the door movement with respect to the cabin of the vehicle (outside or inside), the drive (hand, electric, hydraulic, pneumatic), the number of moving elements of doors, the type of anti-cramping systems, etc.

The structural and kinematic characteristics, as well as the methods of geometrical synthesis of different mechanisms of actuating doors of urban buses are presented in numerous scientific publications. Most of these works (Antonescu et al., 2018; Antonescu et al., 2017) consider the kinematic and geometrical properties of the mechanisms, in particular the swept volume, pressure angles, mechanism stalling etc. The other investigations (Rahman et al., 2014; Kwon \& Suh, 2005) deal with simulation analysis and computer-aided design of the improved door mechanisms of public vehicles. One more group of researchers (Hong et al., 2001; Tushar et al., 2019) studies the peculiarities of pneumatically operated door systems of electric vehicles, in particular noise conditions, operational safety, passengers convenience etc.

The analyzed investigations on the subject of the paper do not cover the problems of energy efficiency of door mechanisms. Thus, the main purpose of this paper consists in comparative analysis of power consumption of different door mechanisms of public vehicles on the basis their structural and kinematic analysis and motion simulation using MathCAD and SolidWorks software.

Materials and methods. While carrying out the research, the structural and kinematic analysis of the six-link hinge-lever door mechanism will be performed using the

Інформація про авторів:

Корендій Віталій Михайлович, канд. техн. наук, асистент, кафедра механіки та автоматизації машинобудування. Email: vitaliy.nulp@gmail.com; https://orcid.org/0000-0002-6025-3013

Коцюмбас Олег Йосифович, канд. техн. наук, ст. викладач, кафедра експлуатації та ремонту автомобільної техніки. Email: o.kotsjumbas@email.ua; https://orcid.org/0000-0002-6590-4022

Ланець Олена Валеріївна, канд. техн. наук, асистент, кафедра технічної механіки та динаміки машин. Email: lanecolena@gmail.com; https://orcid.org/0000-0002-0372-6240

Цитування за ДСТУ: Корендій В. М., Коцюмбас О. И., Ланець О. В. Analysis of technical and operational characteristics of turningand-shunting door opening mechanism of electric public transport. Науковий вісник НЛтУ України. 2019, т. 29, № 3. С. 89-94.

Citation APA: Korendiy, V. M., Kotsiumbas, O. Yo., \& Lanets, O. V. (2019). Analysis of technical and operational characteristics of turning-and-shunting door opening mechanism of electric public transport. Scientific Bulletin of UNFU, 29(3), 89-94. https://doi.org/10.15421/40290319 
well-known methods of the Engineering Mechanics and Theory of Mechanisms, in particular, the method of closed vector loops. In order to carry out experimental investigations and simulation of the mechanism motion, the applied software SolidWorks and MapleSim will be used.

\section{Results}

Substantiation of the investigated design of door portal of public vehicle. One of the most common designs of the door portals of electric public transport is the turningand-shunting configuration (Fig. 1). In this case, the door leaves 1 are hingely joined by the straight levers 2 with vertical drive shafts (tubes) 3 placed on each side of the door portal. Vertical drive shafts 3 have the ability to rotate around their own longitudinal axes and they are driven by the lever mechanisms 4 with a help of pneumatic cylinders 5 . In order to ensure the opening of the door leaves 1 inside the cabin and almost perpendicularly to the body of the vehicle, the guide sliders are attached to the door leaves 1 and move along the guide rail 6 .

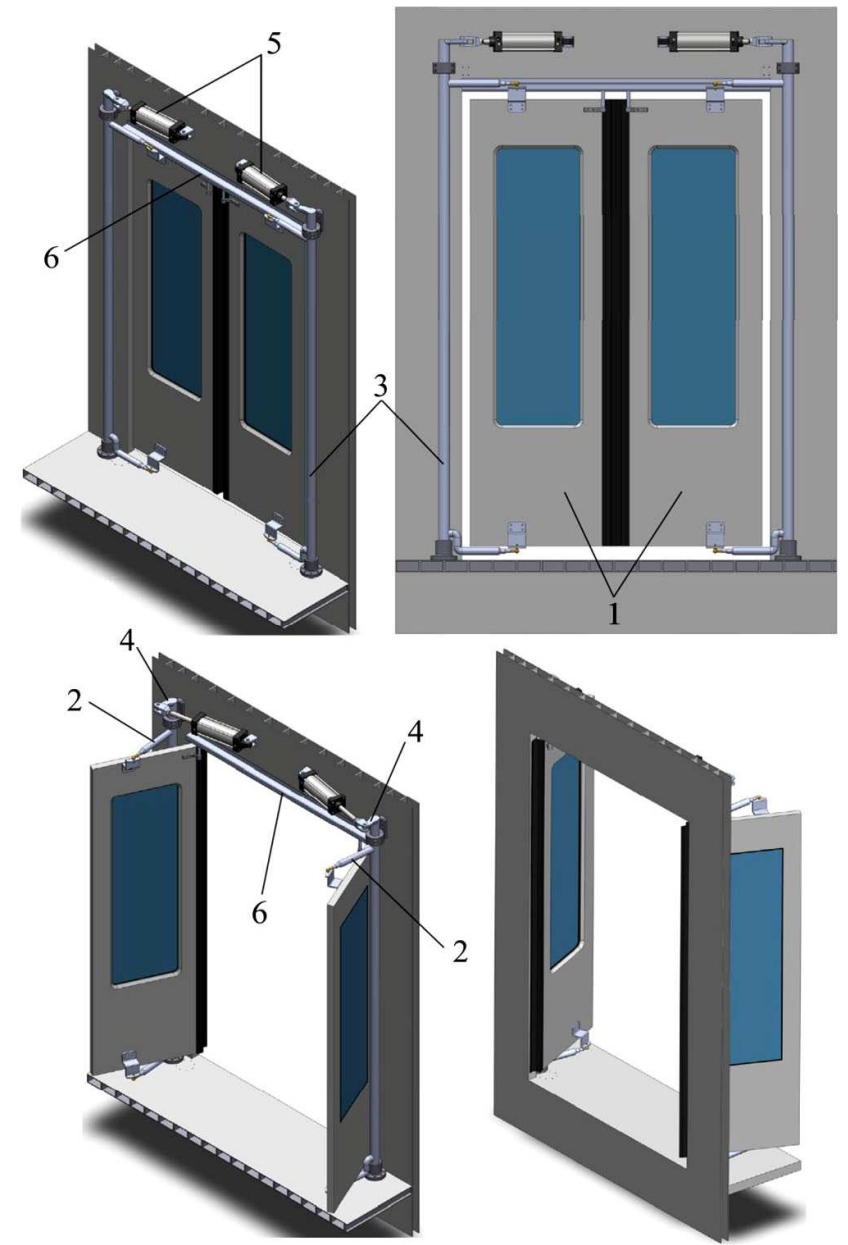

Fig. 1. The analysed design of the turning-and-shunting doors of public transport

Design and kinematic diagrams of the door mechanism. Let us consider the basic design of the turning-andshunting door opening mechanism of electric public transport (Fig. 2, a). It consists of the pneumatic cylinder 1, which is hingely joined with the body 2 of the vehicle. The piston rod of the pneumatic cylinder 3 is hingely connected with the driving rocker 4 of the vertical shaft 5 , to which the door leaf 7 is hingely joined with the help of the lever 6 . To provide a turning-and-shunting way of closing the door, the guide slider 8 , which moves along the horizontal guide rail 9 , is hingely connected with the door leaf 7 . Thus, du- ring the process of pushing the rod 3 (Fig. 2, a) it turns the rocker 4 , shaft 5 and lever 6 . The lever 6 sets the door leaf 7 in motion causing its rotation around the hinge of its attachment to the slider 8 and causing its translational motion along the guide rail 9 .

On the basis of the considered design of the turningand-shunting mechanism for opening the door, let us develop its kinematic diagram (Fig. 2,b). The mechanism consists of the driving slider 1 , the lever 2 of which is connected to the rocker 3 by means of the cylindrical hinge $A$. The other end of the rocker 3 is hingely connected with the rotation axis B. The coupler 4 (presenting the door leaf) is joined with the rocker 3 by means of the cylindrical hinge $C$. The other end of the coupler 4 is hingely connected to the slider 5 at the point $D$. The point $M$ denotes the position of the mass centre of the door leaf.
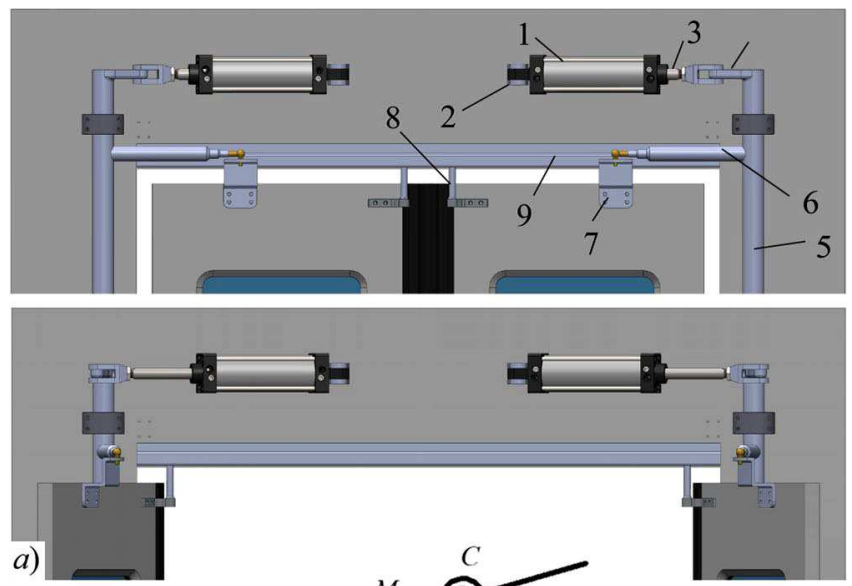

b)

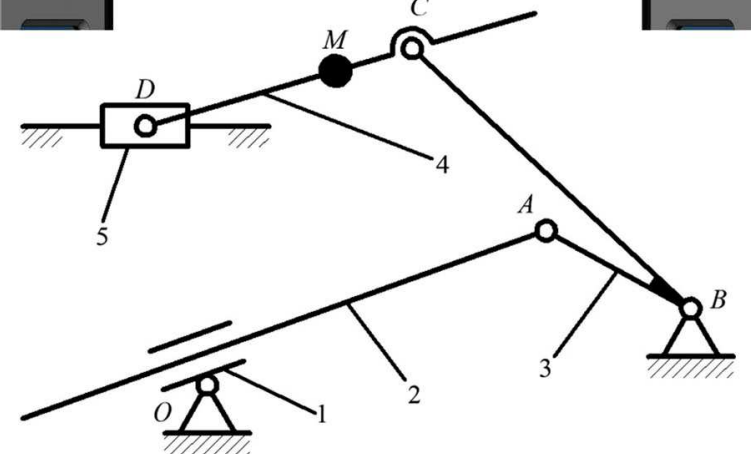

Fig. 2. Design $(a)$ and kinematic $(b)$ diagram of the turning-andshunting door opening mechanism of public transport

Structural and kinematic analysis of the mechanism. The turning-and-shunting mechanism for opening the doors of electric public vehicle consists of five movable links (Fig. 2,b): slider 1, coupler 2, rocker 3, coupler 4, slider 5, and seven single-motion kinematic pairs (kinematic pairs of the fifth order): rotary pairs $O_{1}, A, B, C, D_{1}$, translational pairs $O_{2}, D_{2}$. There are no higher kinematic pairs in the mechanism. Thus, in accordance with the Chebyshev formula for plane mechanisms (Norton, 2004), we have $n=5$, $p_{5}=7, p_{4}=0$, which allows us to determine the degree of freedom of the mechanism:

$$
W=3 \cdot n-2 \cdot p_{5}-p_{4}=3 \cdot 5-2 \cdot 7-0=1 .
$$

Consequently, we can state that the mechanism has one degree of freedom, and therefore it is enough to choose one generalized coordinate to describe the motion of all its links. As the generalized coordinate we adopt the elongation of the piston rod of the driving pneumatic cylinder (see design diagram in Fig. 2,a) or the distance $l_{O A}$ (see kinematic diagram in Fig. 2,b). 
Let us deduce the formula of the mechanism structure. To do this, we have to divide it into Assur's groups (Norton, 2004). As an input (driving) link we accept the slider 1 that can rotate around the hinge $O$. In this case, the slider 1 is considered as a mechanism of the $1^{\text {st }}$ class. The remaining kinematic chain can be divided into two groups of the $2^{\text {nd }}$ class: of the first type (links 2, 3) and of the second type (links 4,5$)$ Thus, the formula of the mechanism structure is following:

$$
\text { Mech }=\mathrm{I}(0,1) \rightarrow \mathrm{II}(2,3) \rightarrow \mathrm{II}(4,5) .
$$

In order to perform kinematic analysis of plain mechanisms of the second class, it is expedient to use the method of closed vector loops (Norton, 2004). To derive the equations of the mechanism links motion, we arbitrary divide it into three triangles: $O A B, A B C$ and $C O D$ (Fig. 2, b). In the first triangle, we know the coordinates of the immovable cylindrical hinge $B-x_{B}, y_{B}$, the length of the rocker $A B-$ $l_{A B}$, and the accepted generalized coordinate (the length of the piston rod of the pneumatic cylinder) $-l_{O A}$. If we accept the centre of the coordinate system at the point $O\left(x_{O}=0\right.$, $\left.y_{O}=0\right)$, then the horizontal coordinate of the hinge $A$ can be determined by the formulas:

$$
\begin{gathered}
x_{A}=x_{O}+\sqrt{l_{O A}^{2}-\left(y_{A}-y_{O}\right)^{2}}=\sqrt{l_{O A}^{2}-y_{A}^{2}} ; \\
x_{A}=x_{B}-x_{O}-\sqrt{l_{A B}^{2}-\left(y_{A}-y_{B}+y_{O}\right)^{2}}=x_{B}-\sqrt{l_{A B}^{2}-\left(y_{A}-y_{B}\right)^{2}} .
\end{gathered}
$$

Equating two expressions (3), we obtain one equation with one unknown value $y_{A}$ :

$$
\sqrt{l_{O A}^{2}-y_{A}^{2}}=x_{B}+\sqrt{l_{A B}^{2}-\left(y_{A}-y_{B}\right)^{2}} .
$$

The solution of the equation (4) has the following form:

$$
y_{A}=\frac{y_{B} \cdot\left(l_{O A}^{2}-l_{A B}^{2}+x_{B}^{2}+y_{B}^{2}\right)+x_{B} \cdot \sqrt{v_{A} \cdot v_{B}}}{2 \cdot\left(x_{B}^{2}+y_{B}^{2}\right)},
$$

where $v_{A}=\left(l_{A B}+l_{O A}\right)^{2}-x_{B}^{2}-y_{B}^{2}, v_{B}=-\left(l_{A B}-l_{O A}\right)^{2}+x_{B}^{2}+y_{B}^{2}$.

Thus, we obtained the analytical expression (5) for describing the vertical coordinate of the hinge $A$ as a function of the generalized coordinate, since the other parameters in the formula (5) are known. If $y_{A}$ is determined, the abscissa of the hinge $A$ can be calculated by the formulas (3).

Let us consider the closed vector loop which is described by the triangle $A B C$ (Fig. 2,b). In this triangle, we know the coordinates of the immovable cylindrical hinge $B-x_{B}$, $y_{B}$, of the hinge $A-x_{A}, y_{A}$, and the lengths of the sides $A B-$ $l_{A B}, A C-l_{A C}$ and $B C-l_{B C}$. The horizontal coordinate of the hinge $C$ can be determined by the formulas:

$$
x_{C}=x_{A}+\sqrt{l_{A C}^{2}-\left(y_{C}-y_{A}\right)^{2}} ; x_{C}=x_{B}-\sqrt{l_{B C}^{2}-\left(y_{C}-y_{B}\right)^{2}} \text {. }
$$

Equating two expressions (6), we obtain one equation with one unknown value $y_{C}$ :

$$
x_{A}+\sqrt{l_{A C}^{2}-\left(y_{C}-y_{A}\right)^{2}}=x_{B}-\sqrt{l_{B C}^{2}-\left(y_{C}-y_{B}\right)^{2}} .
$$

The solution of the equation (7) has the following form:

$$
\begin{gathered}
y_{C}=\frac{v_{A}+v_{B}-\left(x_{B}-x_{A}\right) \cdot \sqrt{v_{C} \cdot v_{D}}}{2 \cdot\left(\left(x_{B}-x_{A}\right)^{2}+\left(y_{B}-y_{A}\right)^{2}\right)}, \\
v_{A}=\left(y_{B}-y_{A}\right) \cdot\left(l_{A C}^{2}-l_{B C}^{2}-y_{A}^{2}+y_{B}^{2}\right) ; \\
v_{B}=\left(y_{B}+y_{A}\right) \cdot\left(x_{B}-x_{A}\right)^{2} ; \\
v_{C}=\left(l_{A C}+l_{B C}\right)^{2}-\left(x_{B}-x_{A}\right)^{2}-\left(y_{B}-y_{A}\right)^{2} ;
\end{gathered}
$$

$$
v_{D}=-\left(l_{A C}-l_{B C}\right)^{2}+\left(x_{B}-x_{A}\right)^{2}+\left(y_{B}-y_{A}\right)^{2} .
$$

Thus, we obtained the analytical expression (8) for describing the vertical coordinate of the hinge $C$ as a function of the generalized coordinate $l_{O A}$, since the other parameters in formula (8) are known. If $y_{C}$ is determined, the abscissa of the hinge $C$ can be calculated by the formulas (6).

Let us consider the closed vector loop which is described by the triangle $C O D$ (Fig. 2, b). In this triangle, we know the coordinates of the fixed cylindrical hinge $O$ $x_{O}=0, y_{O}=0$, the coordinates of the hinge $C-x_{C}, y_{C}$, the ordinate of the hinge $D$ (slider) $-y_{D}$, and the length of the coupler $C D-l_{C D}$. In this case, the horizontal coordinate of the hinge $D$ (slider) can be determined by the formula:

$$
x_{D}=x_{C}-\sqrt{l_{C D}^{2}-\left(y_{C}-y_{D}\right)^{2}} \text {. }
$$

If the coordinates of joints $C$ and $D$ are known, we can determine the coordinates of the point $M$ (mass centre of the door leaf) using the following relationships:

$$
\begin{gathered}
\frac{y_{C}-y_{D}}{l_{C D}}=\frac{y_{M}-y_{D}}{l_{M D}} \Rightarrow y_{M}=y_{D}+\left(y_{C}-y_{D}\right) \cdot \frac{l_{M D}}{l_{C D}} ; \\
\frac{x_{C}-x_{D}}{l_{C D}}=\frac{x_{M}-x_{D}}{l_{M D}} \Rightarrow x_{M}=x_{D}+\left(x_{C}-x_{D}\right) \cdot \frac{l_{M D}}{l_{C D}} .
\end{gathered}
$$

Numerical modelling and simulation of the door mechanisms motion. In order to analyse the adequacy of the analytical relationships for description of the door mechanism motion, let us investigate the displacements of the corresponding links. This stage of research is to be carried out on the basis of the derived analytical dependencies in MathCAD software and using the solid-state model of the door mechanism in SolidWorks software (Korendiy, 2019).

On the basis of the proposed design of the door mechanism developed in SolidWorks software, let us write the input data for investigating the motion of the mechanism, in particular, its geometric parameters (Fig. 2,b): $y_{B}=12 \mathrm{~mm}$, $x_{B}=565 \mathrm{~mm}, l_{A C}=240 \mathrm{~mm}, l_{C D}=395 \mathrm{~mm}, y_{D}=-34 \mathrm{~mm}$, $l_{B C}=330 \mathrm{~mm}, l_{A B}=96 \mathrm{~mm}, l_{M D}=395 \mathrm{~mm}$.

Based on the formulas (3)-(10), let us plot the graphical dependences of the displacements of the corresponding hinges and of the mass centre of the door leaf on the magnitude $l_{O A}$ of the elongation of the piston rod of the pneumatic cylinder (Fig. 3).

To confirm the adequacy of the obtained analytical dependencies, let us present the results of motion simulation of the mechanism received in SolidWorks software (Fig. 4) (Korendiy, 2019). During the process of simulation, a constant speed of the piston rod motion was accepted. This provides a 2 seconds duration of the door closing cycle. Thus, the length of the piston rod varies from the minimum value $l_{O A \min }=474 \mathrm{~mm}$ to the maximum value $l_{O A \max }=586$ $\mathrm{mm}$ in accordance with the linear dependence on time.

Analysing the graphic dependences presented in Figs. 3-4 obtained on the basis of analytical calculation and virtual experiment, respectively, we can state about their satisfactory agreement (convergence), which justifies the adequacy of the derived equations of motion of the turning-andshunting door opening mechanism.

Discussion. The turning-and-shunting door mechanism of electric public transport (Figs. 1-2) is currently considered as one of the safest and most comfortable mechanisms. However, among its disadvantages we can mention the necessity to use the drive with a significant power store, when it is required to close the doors in the case of overcrowded passenger cabin. 

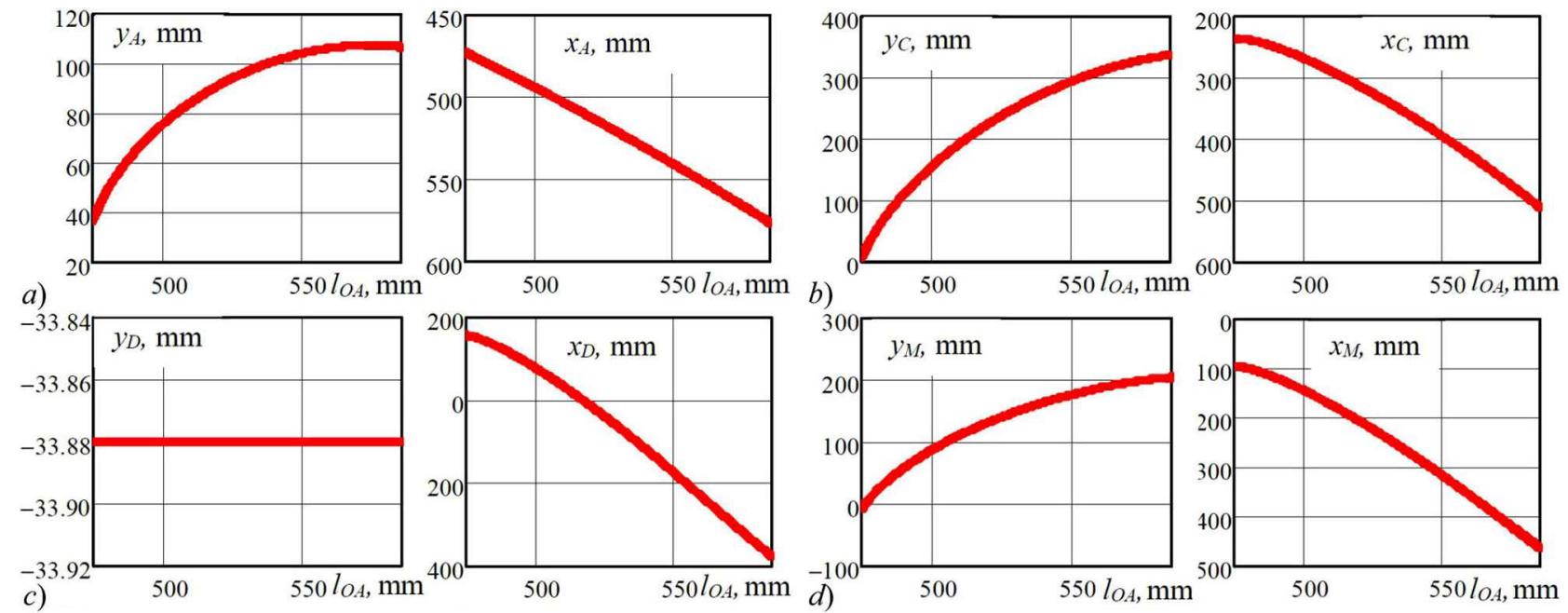

Fig. 3. Results of numerical modelling of motion of the turning-and-shunting mechanism: $a$ - hinge $\mathrm{A}, b$ - hinge $\mathrm{C}, c-$ hinge $\mathrm{D}, d$ - mass centre of the door leaf
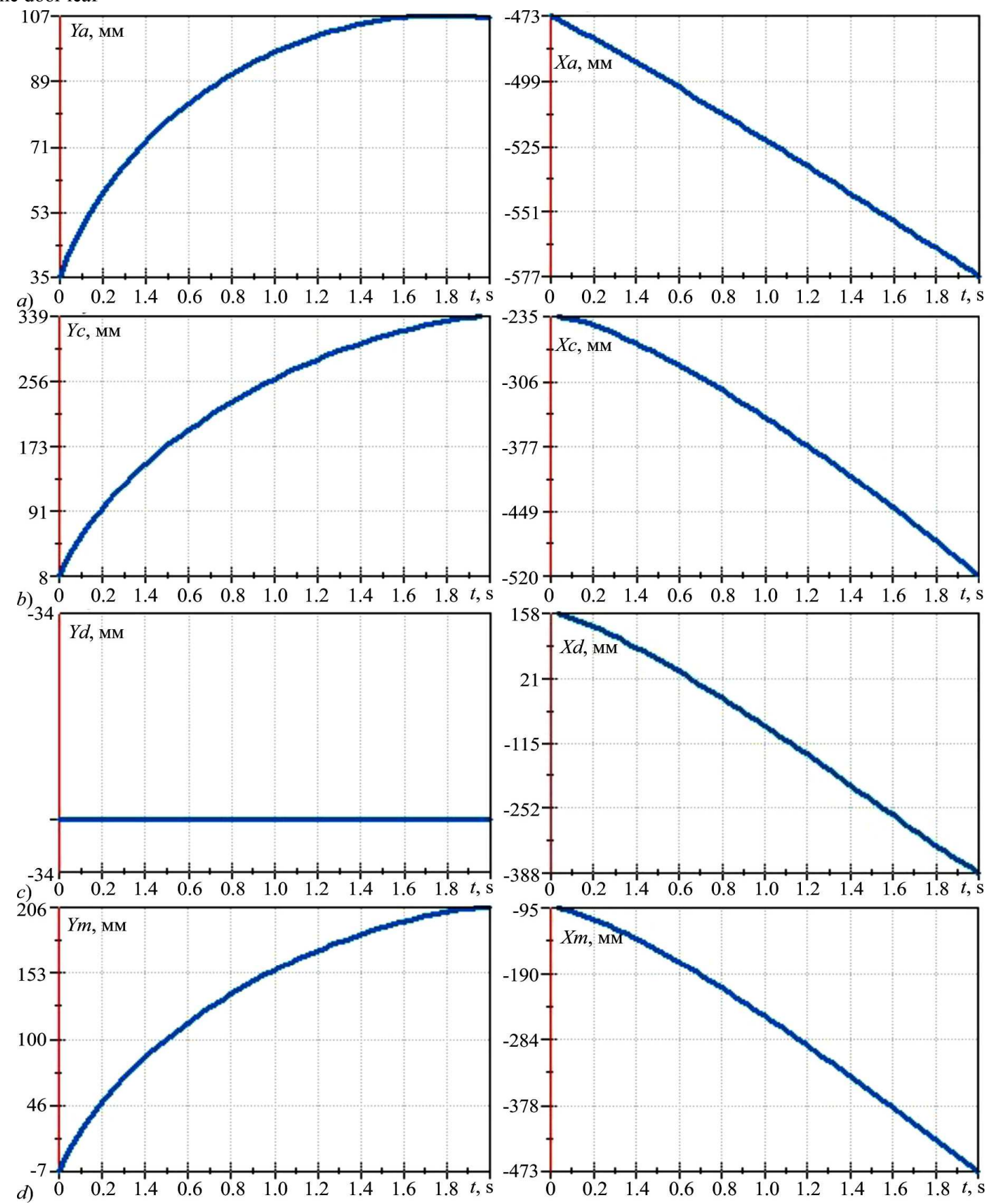

Fig. 4. Results of motion simulation of the turning-and-shunting mechanism: $a$-hinge $\mathrm{A}, b$-hinge $\mathrm{C}, c$-hinge $\mathrm{D}, d$-mass centre of the door leaf 
Let us consider the problem of providing the necessary power of the mechanism drive while closing the doors of the electric public transport in the presence of obstacles on their way. The obstacles are simulated in the form of a constant forces applied to the ends of the door leaves and directed oppositely to the direction of their closing. The value of the resistance force is $F_{r}=100 \mathrm{~N}$. To find the nominal power of the drive, which is required to overcome the given force, taking into account the specified duration of the door closing cycle $T_{c}=2 \mathrm{~s}$, we need to determine the speed of the guide hinge $D$ parallel to the body of the vehicle, that is, the speed $\dot{x}_{D}$. To find this speed, it is necessary to differentiate the dependency (9) considering the function $\dot{x}_{D}$ as a complex function, which depends on the elongation of the piston rod of the driving pneumatic cylinder, which in turn is a function of time. Therefore, the general expression for calculating the speeds $\dot{x}_{D}$ is following:

$$
\dot{x}_{D}(t)=\frac{d\left(x_{D}\left(l_{O A}\right)\right)}{d\left(l_{O A}\right)} \cdot \frac{d\left(l_{O A}(t)\right)}{d(t)} .
$$

As mentioned above, the speed of the elongation of the driving pneumatic cylinder rod, which provide a two-second cycle of the door closing, is constant:

$$
\frac{d\left(l_{O A}(t)\right)}{d(t)}=\text { const }=56 \mathrm{~mm} / \mathrm{s}=0,056 \mathrm{~m} / \mathrm{s} .
$$

Considering the expression (12), we can state that:

$$
l_{O A}(t)=0,056 \cdot t(\mathrm{~m}) .
$$

Taking into account the awkwardness of the derivative expression $\frac{d\left(x_{D}\left(l_{O A}\right)\right)}{d\left(l_{O A}\right)}$, it is inexpedient to present this expression in the paper, but it has been deduced and accepted for modelling with a help of MathCAD software.

Adopting the resistance force while closing the doors $\mathrm{Fr}$ $=100 \mathrm{~N}$ and calculating the corresponding speed of the door motion (formula 11), we can determine the dependence of the nominal power of the doors drive on the corresponding generalized coordinate:

$$
N\left(l_{O A}\right)=F_{r} \cdot \frac{d\left(x_{D}\left(l_{O A}\right)\right)}{d\left(l_{O A}\right)},
$$

and time dependence of changing the nominal power of the doors drive during the process of their closing under the action of constant resistance force:

$$
N(t)=F_{r} \cdot \frac{d\left(x_{D}\left(l_{O A}\right)\right)}{d\left(l_{O A}\right)} \cdot \frac{d\left(l_{O A}(t)\right)}{d(t)} .
$$

The results of calculations performed by the formula (14) are shown in Fig. 5, $a$, and the results of the virtual experiment carried out in SolidWorks software are presented in Fig. 5,b (Korendiy, 2019).

Analysing the obtained graphical dependences (Fig. 5), for the constant resistance force opposing the motion of the door leaves $\mathrm{Fr}=100 \mathrm{~N}$ and for the constant duration of the door closing cycle $T c=2 s$, we can state that the required nominal power of the pneumatic drive is approximately $580-600 \mathrm{~W}$. This power is about twice larger than the required nominal power of the electric drive of the leaningand-shunting doors that are widely used in modern electric public transport (Antonescu et al., 2018; Antonescu et al., 2017).

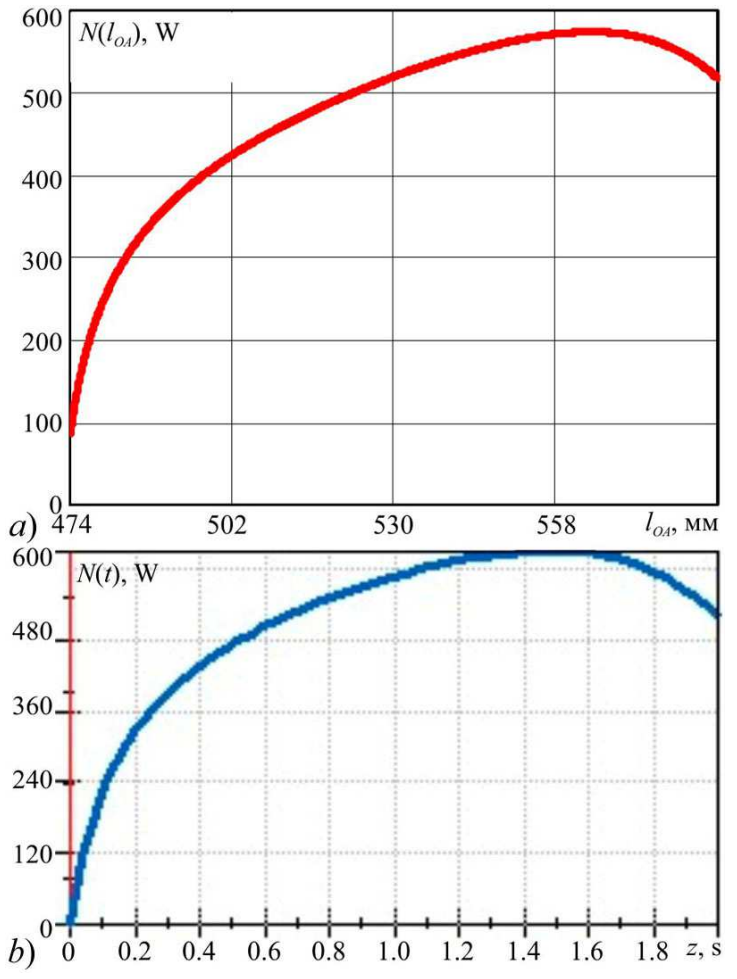

Fig. 5. Results of analytical and experimental analysis of the nominal power of the door opening mechanism drive of electric public transport: $\mathrm{a}$ - obtained on the basis of the derived analytical dependencies in MathCAD software; $b$ - obtained by means of the mechanism motion simulation in SolidWorks software

Conclusions. The design and operational peculiarities of the turning-and-shunting door mechanism of electric public transport were considered. On the basis of the constructed simplified diagram of the mechanism its structural and kinematic analysis was performed. As a result of the carried out analysis, the analytical dependencies for describing the motion of the mechanism links during the door motion were derived. Using the obtained expressions, the main kinematic parameters of the studied mechanism were investigated in MathCAD software. The virtual experiment was carried out by means of simulating the motion of the solid-state model of the mechanism designed in SolidWorks software. The results of theoretical investigations and of the virtual experiment justified the adequacy of the derived analytical expressions. The energy efficiency of the investigated turning-and-shunting door opening mechanism of electric public transport was analyzed. While performing energy efficiency analysis, the resistance force acting on the door leaves was prescribed $(\mathrm{Fr}=100 \mathrm{~N})$ and the corresponding door motion speed during its closing was calculated. Based on the obtained results the dependency of the nominal power supply of the mechanism drive as a function of corresponding generalized coordinate was deduced. Comparing the obtained results with the investigations presented in modern scientific publications, it was established that the necessary nominal power of the turning-and-shunting mechanism drive is almost twice larger than the necessary nominal power of the leaning-and-shunting mechanism that is widely used in modern electric public transport. Further investigations on the subject of the paper can be carried out in the direction of developing different control systems providing safe and reliable operation of the considered door opening mechanism driven be electric and pneumatic actuators. 


\section{Перелік використаних джерел}

Antonescu, D. (2017). The actuating mechanisms of the urban buses doors. Annals of "Constantin Brancusi" University of Targu-Jiu. Engineering Series, 3, 117-122.

Antonescu, D., Brezeanu, C., \& Antonescu, O. (2018). Topological Structure of the Actuating Mechanisms of the Urban Buses Doors. In I. Doroftei, C. Oprisan, D. Pisla, E. Lovasz (Eds). New Advances in Mechanism and Machine Science. Mechanisms and Machine Science, 57, 75-86. Cham: Springer. https://doi.org/10.1007/978-3319-79111-1 8

Antonescu, D., Popescu, I., \& Antonescu, O. (2018). Geometric Synthesis of the Actuating Mechanisms of Urban Bus Doors. In I. Doroftei, C. Oprisan, D. Pisla, E. Lovasz (Eds). New Advances in Mechanism and Machine Science. Mechanisms and Machine Science, 57, 87-98. Cham: Springer. https://doi.org/10.1007/978-3$\underline{319-79111-19}$

Korendiy, V. M., et al. (2019). Systems of $3 D$ modelling. Kamyanske: DSTU, 152 p.
Hong, J., et al. (2001). Development for pneumatic plug door system. Proceedings of the Fifth World Congress on Railway Research, Cologne, Germany, November 25-29.

Kwon, S.-J., \& Suh, M.-W. (2005). Design program for the kinematic and dynamic characteristics of the bus door mechanism. Journal of Automotive technology, 6(4), 403-411.

Norton, R. L. (2011). Design of Machinery: An Introduction to the Synthesis and Analysis of Mechanisms and Machines. Massachusetts: McGraw-Hill Education, 857 p.

Rahman, Hafizur, et al. (2014). Design of an Accessible Door System in High Floor Buses for Wheel Chair Users. Proceedings of the International Conference on Mechanical, Industrial and Energy Engineering, Khulna, Bangladesh, December 25-26. https://doi.org/10.13140/2.1.2698.1443

Tushar, A. B., et al. (2019). A Review on Pneumatic Operated Train Door System. International Research Journal of Engineering and Technology, 6(1), 472-477.

В. М. Корендій, О. Й. Коцюмбас, О. В. Ланець

Національний університет "Львівська політехніка", м. Львів, Україна

\section{АНАЛІЗ ТЕХНІКО-ЕКСПЛУАТАЦІЙНИХ ХАРАКТЕРИСТИК ПОВОРОТНО-ЗСУВНОГО МЕХАНІЗМУ ВІДКРИВАННЯ ДВЕРЕЙ ПАСАЖИРСЬКОГО ЕЛЕКТРОТРАНСПОРТУ}

Проаналізовано конструктивні і функціональні особливості поворотно-зсувного механізму відкривання дверей пасажирського електротранспорту. Запропоновано відповідне конструктивне виконання механізму з використанням пневматичного приводу та побудовано його спрощену розрахункову схему. Проведено структурний і кінематичний аналізи механізму та виведено аналітичні залежності для опису руху його ланок у процесі відкривання/закривання дверей. Досліджено основні кінематичні параметри запропонованого механізму на основі виведених аналітичних залежностей у програмному продукті MathCAD та з використанням його твердотільної моделі, розробленої у середовищі SolidWorks Motion. Зроблено висновки про узгодження результатів теоретичних досліджень, проведених на основі чисельного розв'язування отриманих рівнянь руху, та віртуального експерименту (імітаційного моделювання у програмному продукті SolidWorks). Проаналізовано енергоефективність досліджуваного поворотно-зсувного механізму відкривання дверей пасажирського електротранспорту. Задаючи зусилля опору закривання дверної стулки та розрахувавши відповідну швидкість руху дверей у процесі їх закривання, встановлено залежність номінальної потужності пневматичного приводу механізму як функції відповідних узагальнених координат. Аналізуючи отримані результати, встановлено, що необхідна номінальна потужність приводу поворотно-зсувного механізму практично вдвічі перевищує необхідну номінальну потужність приводу дверей, в яких використовується поширений на цей час притульно-зсувний механізм.

Ключові слова: поворотно-зсувний механізм; пасажирський електротранспорт; структурний аналіз; кінематичний аналіз; енергетична ефективність. 